\title{
A HISTORICAL REVIEW OF THE RIVER BASIN MANAGEMENT IN KOREA
}

\author{
By \\ LEE, MON-HWAN \\ * Professor of Civil Engineering, Yonsei University \\ 134 Shinchon-Dong, Seodaeaun-Ku, Seoul 120-749, Korea
}

\begin{abstract}
In the Korean peninsula, which is located at the southern edge of north-east Asia, the 24th olympic game was held on Sept., 1988 in Seoul, the capital city of Republic of Korea. Since the Neolithic Age, the Han River of the 481 kilometer-long flowing through the heart of the Korean peninsula and bisecting Seoul into northern part and southern part, not only has been the nation's political, economic, industrial and cultural center, but also has played major roles in the national defence and security. The Han River also has seen brilliant cultures arise and flourish in its basin, which has left the area with abundant legacy of relics and scores of legends and myths.

To the Korean people, the river has been a fear complex of frequent flood damage. Perhaps this must have been a common conception for the most Asian. It seems for hydrologic characteristics of the rivers in Korea that rapid flow and meandering were intensive. For a long period of time, the Korean people lived with carelessness about the river management, thus there were many sufferings from floods and droughts damage which occurred in turn.

In the beginning of 20 th century, a great flood attacked with unprecedented quantity in the Han River Basin. This flood occurred in 1925 and was recorded as the largest flood up to now. The purpose of this study, because the managements of the Han River Basin have been changed in several ways, is to analyze and to summarize its contents and to go far for river management in the future. The results of the study are summarized by the stages with definition of their major characteristics and activities as follows; Natural river condition with waterway transportation, (until 1910), Channel improvement works with water control (1910-1945), riverside development project with increasing of land use (1946-1960), water resources and hydropower generation project with water use(since 1960), comprehensive the Han River development projects with protection of environment, flood control, and water use (since 1980).
\end{abstract}

\section{KEYWORDS}

The Han River Basin; River Management System; Floods and Dams, Amendments of the River Law.

\section{INTRODUCTION}

The Korean peninsula, located in the north - east of Asia, has the total population of 60 millions, the total area of $220,000 \mathrm{~km}^{2}$ and the long history of 4,300 years. The Aprock (Yalu) River, the longest river in Korea and the Dooman(Tumen) River are bordering on Manchuria of China and Vladivostok of the U.S.S.R. respectively. Also, because the Taebrack mountains lies on the east part of the peninsula, most of the main river system are in the direction of west or south of the peninsula.

The Han River Basin is one of the 38 direct managing rivers, which are managed directly by the Ministry of Construction of Korea. Because it not only lies on the center of the Korean peninsula, but also passes through Seoul, it is the center of the politics, economics, culture and industry of the peninsula. So, the object of this study, because the managements of the Han River Basin have been changed in several ways, is to analyze and to summarize its contents and countermeasures simultaneously for river management in the future. 


\section{FLOODS AND CONSTRUCTION OF DAMS}

The Han River Basin consists of two large streams, the South Han River and the North Han River. The main stream is the South Han River, which has the basin area of $26,219 \mathrm{Km}^{2}$ and the length of $481.7 \mathrm{Km}$.

Hydrologic characteristics in the Han River Basin well present the hydrometeorologic characteristics in the Korean peninsula. Because the summer monsoon season has floods frequently and the droughts are in the winter, the ratios of the maximum discharge to the minimum discharge are up to $300 \sim 700$. The maximum flood data are recorded on July 18 19, 1925.

The first dam in the Han River Basin is Cheongpyung dam completed in 1943 to supply the electric power. Since then 6 dams were constructed in the North Han River Basin, two dams in the South, and one(Paldang) dam on the junction of the two main streams. There is also 1 planning dam in the brench of the North Han River.

Past major flood data in the Han River Basin are listed on table 1 and characteristics of each dam in the Han River Basin are summarized in table 2.

TABLE 1. Major Flood Data at the Indogyo Station

(Normal Water Level : El. +0.40 m)

\begin{tabular}{l|cccc}
\hline Rank & Date & Max. Water Level & Max. Flow Rate \\
& & $($ El. m) & $\left(\mathrm{m}^{3} / \mathrm{sec}\right)$ \\
\hline 1 & 1925.7 .18 & 12.26 & 32,361 \\
2 & 1972.8 .19 & 11.25 & 30,000 \\
3 & 1984.9 .2 & 11.03 & 26,571 \\
4 & 1865.7. & 10.91 & 26,000 \\
5 & 1965.7 .16 & 10.80 & 25,900 \\
6 & 1966.7 .26 & 10.78 & \\
\hline
\end{tabular}

TABLE 2. Characteristics of Each Dam in the Han River Basin

\begin{tabular}{|c|c|c|c|c|c|c|}
\hline $\mathrm{Dam}$ & $\begin{array}{l}\text { Design } \\
\text { Flood } \\
\left(\mathrm{m}^{3} / \mathrm{s}\right)\end{array}$ & $\begin{array}{l}\text { Spillway } \\
\text { Capacity } \\
\left(\mathrm{m}^{3} / \mathrm{s}\right)\end{array}$ & $\begin{array}{l}\text { Gate } \\
b^{m} \times h^{m} \\
\text { (No.) }\end{array}$ & $\begin{array}{l}\text { Flood } \\
\text { Water Level } \\
\text { (EL. m) }\end{array}$ & $\begin{array}{l}\text { Normal } \\
\text { Water Level } \\
\text { (EL.m) }\end{array}$ & $\begin{array}{l}\text { Flood Control } \\
\text { Capacity } \\
\left(10^{6} \mathrm{~m}^{3}\right)\end{array}$ \\
\hline Hwacheon & 9500 & 5428 & $\begin{array}{l}12 \times 6(12) \\
12 \times 8(4)\end{array}$ & 183.0 & 181.0 & 213 \\
\hline Chuncheon & 12600 & 12600 & $12 \times 12.9(12)$ & 104.9 & 103.0 & 13 \\
\hline Soyanggang & 10500 & 5500 & $13 \times 13(5)$ & 198.0 & 193.5 & 501 \\
\hline Euiam & 16600 & 16000 & $13 \times 14.5(14)$ & 73.36 & 75.5 & 16 \\
\hline Che ongpyung & 20200 & 20736 & $12 \times 10(24)$ & 52.0 & 51.0 & 19 \\
\hline Chungju & 16000 & 16000 & $15 \times 17.9(6)$ & 145.0 & 141.0 & 616 \\
\hline Guesan & 2711 & 3080 & $8 \times 7(7)$ & 136.93 & 135.65 & - \\
\hline Paldang & 38000 & 34400 & $20 \times 16.75(15)$ & 29.5 & 25.5 & - \\
\hline Hongche on ${ }^{*}$ & 5390 & 3194 & & 123.6 & 121.0 & 126 \\
\hline
\end{tabular}

* Planning Dam 


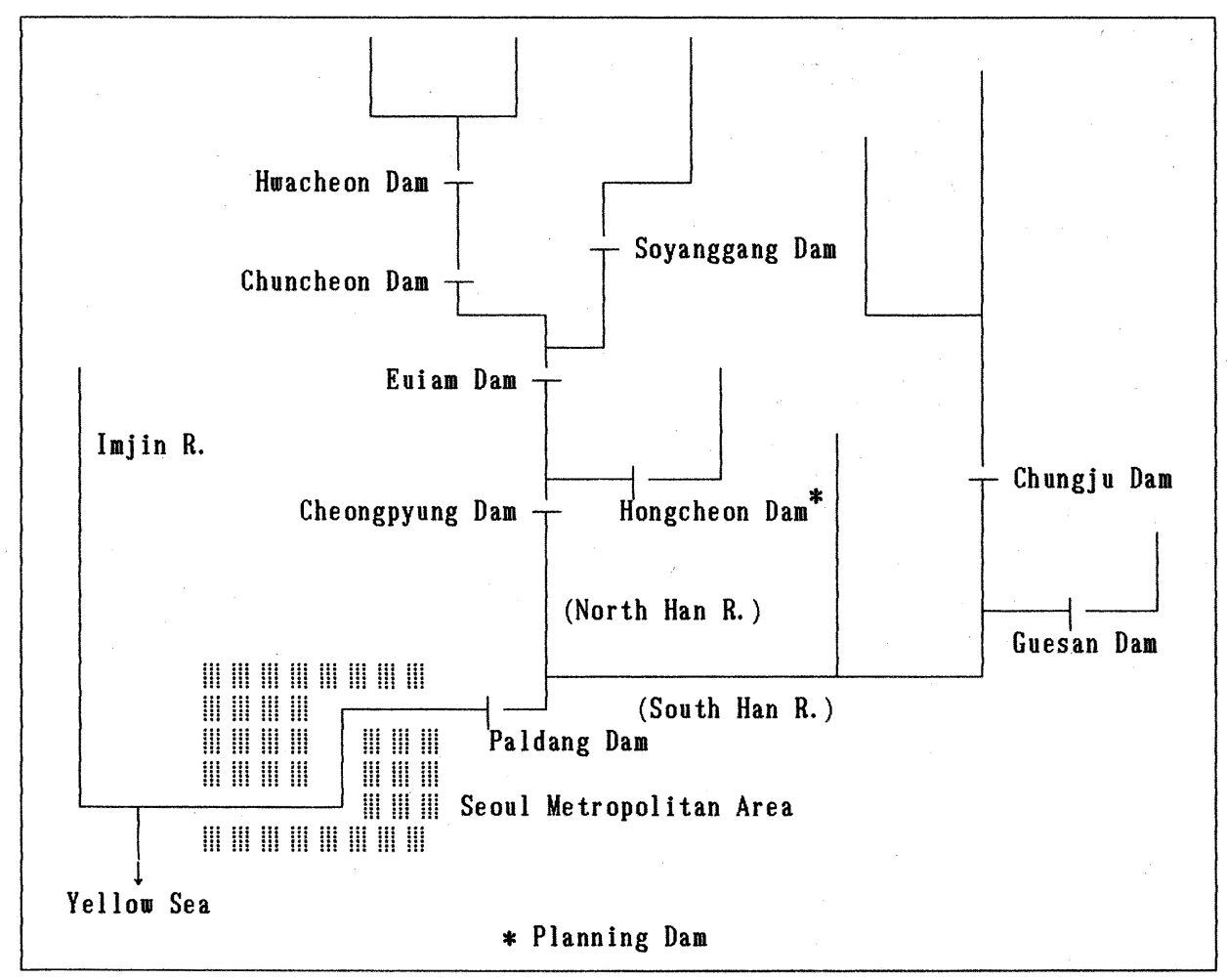

Fig. 1 Schematic Map of the Han River Basin and Location of Dams.

\section{CHANGES OF MANAGEMENT SYSTEM IN THE HAN RIVER BASIN}

\section{CHRONICAL CLASSIFICATION}

Since the Building Bureau was established in 1392 (the first year of the Choseon (Lee) Dynasty), the managing system in the Han River Basin had transfigured as follows: the Geographic Bureau and the Civil Engineering Bureau of Department of Home Affairs in 1895, Section of Public Works of the Bureau of Local Administration or the Official Engineering Bureau in 1910, were established respectively. After 1948 the Construction Bureau was set in the government and in later it was elevated as the Ministry of Construction.

The old stage: before 1910
The 1st stage : $1910 \sim 1945$
The 2nd stage : $1945 \sim 1960$
The 3rd stage : $1960 \sim 1980$
The 4th stage : after 1980

The above classification of stages is based on the change of government systems rather than ages. The techniques and the projects of the channel improvement and river basin management were diversified with the change of river management system.

The old stage is defined until the beginning of $20 \mathrm{C}, 1910$. During the period, lots of levee and reservoir were constructed and observations of water level in the Han River were started from the early 15C, the period of King Sejong (1418 1450), using Supyo (Staff Gauge) and Hydrologic observation including measurement of rain depth was also started actively but it was continued intermittently for hundred years until the end of $19 \mathrm{C}$. 
This satge can be subdivided as follows;

I. The Era of the Three Kingdons : the below reservoirs were constructed.

Kimje Byuckgol je Dike (金堤 珵骨是) - ( $\approx 1350 \mathrm{~m}): A D 330$

Youngcheon Cheongje Dike (永川 蓄堤) (AD 530 - 596)

Si je Dike（矢堤）

Jecheon Euirimji Reservoir（堤川 義林池）

Daejeji Reservoir (大堤池)

Susanje Dike (守山堤)

Sangju Gonggeomj i Reservoir (向州 恭儉池)

II. The Era of the Koryeo : AD 918 - 1392

The era of the high degree of adaptability to the nature, rather than the conquest of the nature.

almost nothing on the flood control and water use.

III. The Era of the Choseon (Lee) Dynasty :

First Term : AD $1392-1494$

102 years from the first year of King Taejo to the 25 th

year of King Seongjong : term of flourishing

Second Term : AD $1495-1639$

144 years from the first year of King Yeonsankun to the

17 th year of King Injo : term of stagnation

Third Term : AD $1640-1800$

160 years from the 18 th year of King Injo to the last year

of King Jeongjo : term of restoration

Fourth Term : AD $1801-1910$

109 years from the first year of King Sunjo to the year

of the Japanese annexation of Korea : term of declination

The first stage is the period that focused on flood control by bank construction. The second stage is the period from 1945, the year of ending World War II, to 1960 . During the period, Korean peninsula was divided into two part, the North and the South as the results of Korean War of $1950 \sim 1953$. Korea was in the great social disorder, lack of foods and electric power. In this period, the channel improvements and basin managements were in stationary state, but after the mid of 1950 . The recognitions of water resource and hydraulic simulation were started.

The third stage is the period from 1960 to 1980 . The period is the regeneration period in sense of country development and economic development of Korea. There have been numerous studies made of the water resources of the Han River Basin. Some of these were concerned with only a part of the river and others were basinwide. Nearly all of the studies have emphasized power generation. Republic of Korea (ROK) Government agencies have studied the Han River ever since liberation from the end of World War II. The Ministry of Construction has been concerned with various phases of river development. Its major studies have been conducted through private engineering firms, or by special investigation teams and consultants. The Korea Electric Company has made or caused to be made hydropower studies in the river basin. The Union of Land Improvement Associations, which was absorbed in 1970 by the Agricultural Development Corporation, has investigated and constructed many irrigation projects in the basin, but none of these has involved reservoirs on the mainstream of the Han River or on major tributaries.

The River Basin Survey Team for 4 large rivers of Korea was organized to provide a comprehensive masterplan for the orderly and economic development of the total water resources potential of the river basins. This included both ground water and surface water.

The comprehensive plan was concerned with making available, as required for future growth, maximum firm water supplies for municipalities, industry, and irrigation. The plan also provides for electric power generation and flood control, and considers navigation, fish and wildlife conservation, recreation, and pollution control. The plan was designed to provide maximum development of the available water resources consistent with economic principles. Works required for distribution of the water irrigation and for municipal and industrial purposes were not included in the plan. 
With respect to ground water, the plan showed in a general way where the recoverable ground water was located what kind of equipment and techniques would be required to develope the ground water, and approximately what volumes of water could be expected from the various aquifers.

Other objectives of the survey were to establish hydrologic network (river gage stations for surface water and observation wells for ground water) and to train personal in the use of equipment, maintenance of the stations and wells and processing of the data obtained.

Training was an important part of the program. On-the-job training was carried on from day to day in the field and in the office as part of the regular work of the survey team.

In the studing the water resources of the Han River Basin and developing the plan, it was necessary to make various related surveys and studies. These included basic engineering surveys, geologic examinations, ground water surveys, hydrologic surveys and studies, electric power studies, flood control and navigation surveys and studies, economic analysis and forecasts, estimates, and benefit studies.

There have been many investigations of individual projects, mostly for hydropower and for flood control by means of levees.

As a result, a sufficient water could be coped with the increased demands until now. But, because of the lack of plan for the water quality, water quality problems including sewage and waste water disposal have occurred.

The fourth stage is the period from 1980 to present. The faced tasks are the solution of the problems of the increases of the water demand and the load of water pollution which must be solved simultaneously. The problems of small rivers, especially the urban river systems, rather than the large rivers are come to the front with difficulty through the urban hydrologic projects.

\section{LEGAL CLASSIFICATION OF THE RIVER AND IUPROVEMENTS}

Figure 2 shows the legal classification of the river system in Korea and the number and the total length of the rivers belong to each category. Total length of channel improvements in each category of the legal classification of the legal river at the end of 1987 as follows : 2,320.4 $\mathrm{Km}$ of the Direct Managing River, $877.5 \mathrm{Km}$ of the Local Managing River, and $15,528.7 \mathrm{Km}$ of the Semi-Local Managing River. Total percentage of the channel improvement is $52.3 \%$.

THE LEGISLATION AND AUENDUENTS OF THE RIVER LAT

THE LEGISLATION OF THE RIVER LAW : DEC. 31, 1961

To prevent or reduce the damages by the river water and to increase the profits of using the rivers, the river law including the provisions of the legal classification, specific control, water use, preservation of the rivers, and its expenses, was legislated in Dec. 31,1961 .

THE FIRST ALENDIENT OF THE RIVER LAW FOR A PRESCRIBED PERIOD : DEC. 5, 1963

The manaing authorities confirm the river basin until the relating drawings of the river basin are established by the authorities. Revision of provisions was done by the change of the government organization.

AMENDMENT OF FULL TEXT OF THE RIVER LAW" : JAN. 19, 1971

The notification system for the determination of the river basin was changed to the legislation system. The manaing authorities can form and enforce the fundamental plan for the maintenance and improvement of the river. And also the authority can use the watchman for the river management.

\section{AMENDMIENT OF THE RIVER LAW BY PARTS : MARCH 31, 1981}

Establishment of the foundations of prearrangement of the zone of the river and organization of the committee for the river managent. A provision of a punished person, who 
gathered deposited soil or aggregates from the river without permission, is prohibited to get the permission of gathering for a prescribed period by the law, is added to the river law.

THE SECOND AMENDMENT OF THE RIVER LAI FOR A PRESCRIBED PERIOD : DEC. 31, 1984

The detailed enforcement regulations for compensation for a loss of land where become a part of zone of the river and a land in the outside of the levee being state-owned by the amendment of the river law on Jan. 19,1971, are established and are effective for 5 years from the date of comming into effect of this law.

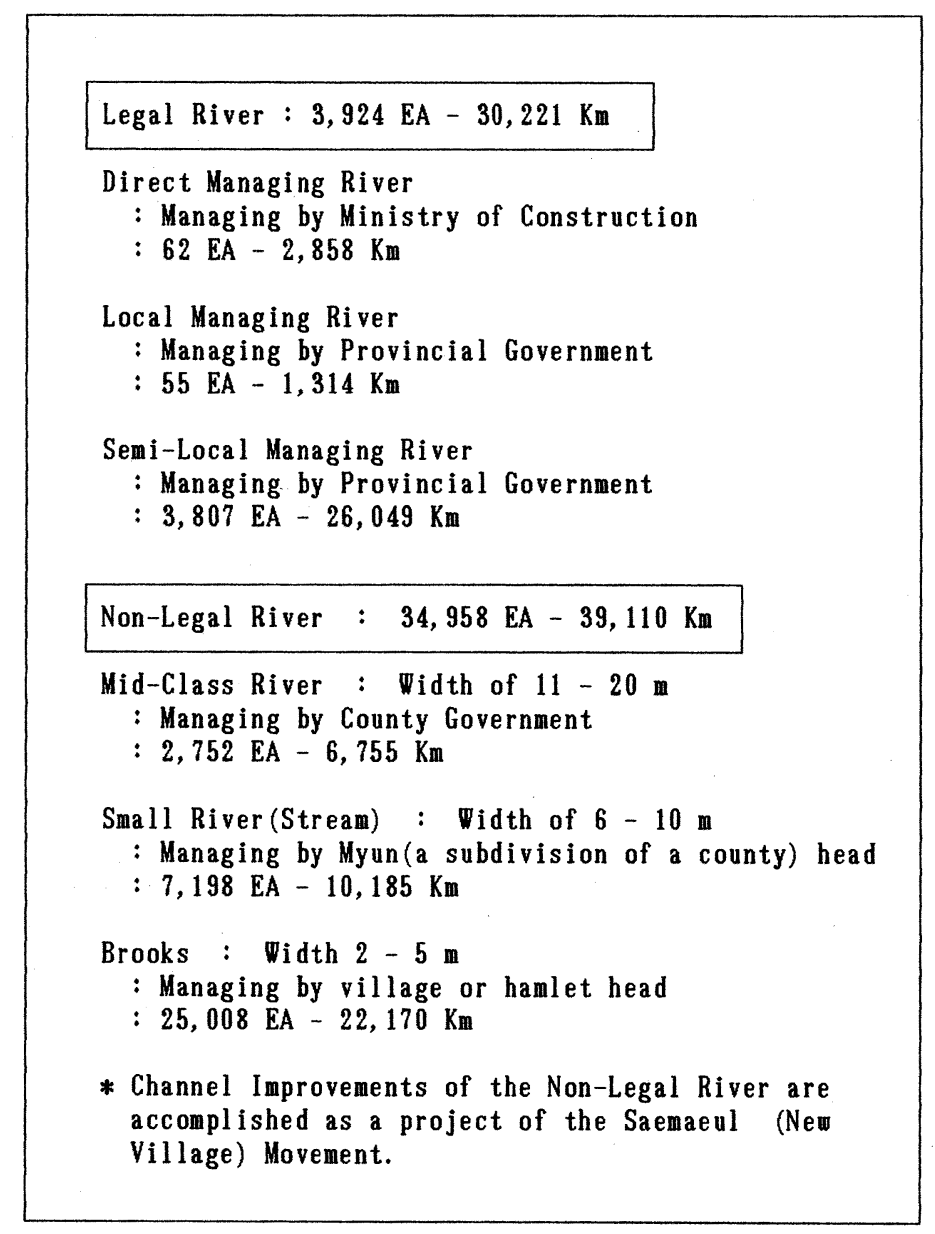

Fig 2. Schematic Diagram of Legal Classification of the River System in Korea

\section{CURRENT TOPICS}

The largest flood, occurred on July 18, 1925 in the Han River Basin, has been used as the basic design criteria in the planning of the river improvement in the basin.

Even though dams in the Han River Basin possess both hydro-power development and capacity of the flood control, the costs of flood damages were increased in 1970's and $1980^{\prime} \mathrm{s}$. 
Regardless of developments of science and technics and expanding of the river managing authority, the current problems are as follows:

1) Even though dams have the capacity of flood control, the flood frequency, cost of flood damages and loss of life are increasing, especially in the downstream of the Han River Basin.

2) In the downstream of the Han River, the load of the water pollution is increasing because the river width was reduced and the river bed was lowered for over-gathering of river bed material and the velocity was also slowered due to the two submerged dams for maintaining of service water level.

3) To control the water quality, four local wastewater treatment plants are now operating in the metropolitan of Seoul, but not sufficient.

4) During the dry weather, the urban streams of the Seoul become dry because the domestic wastewater collecting lines are in operation.

5) Many projects for hydrologic, hydraulic, environmental and ecologic investigation and urban stream management are coming to the front in the urban river basin.

\section{CONSIDERATIONS}

The Han River has the basin area of $26,219 \mathrm{Km}^{2}$ (or $34,473 \mathrm{Km}^{2}$ including the basin area of the Imjin River which joins the Han River at the mouth of each river) and the length of $481.7 \mathrm{Km}$. So the Han River is the 3rd largest after the Yalu and the Tumen River. The Yalu River has the basin area of $62,638.7 \mathrm{Km}^{2}$ (the left side having the area of $30,143.2 \mathrm{Km}^{2}$ belong to Korea and the right side belong to China) and the length of $790.4 \mathrm{Km}$ ( $773 \mathrm{Km}$ along the left bank) and the Tumen River has the basin area of $42,242.9 \mathrm{Km}^{2}$ (the $r i g h t$ side having the area of $18,381.83 \mathrm{Km}^{2}$ belong to Korea and the other side belong to China and U.S.S.R.) and the length of $520.5 \mathrm{Km}$ ( $479 \mathrm{Km}$ along the left bank).

The Han River is located in the middle of Korean peninsula. The Han River passes through from the east to the west of Seoul Metropolitan Area and has the annual water resources of 3.22 billions cubic meter and generate hydro-power of 1.37 millions kilowatts $(\mathrm{Kw})$.

In the latter half of 20 th century, the channel improvements and the developments of hydro-power in the Han River are undertaken actively. But the Han River's comprehensive development is insufficient for demanding of navigation. Populations in the Han River Basin are more than a quarter of the total population of Korea and the most of them reside in the Seoul Metropolitan Area. So, the problems of the wastewater treatment, increasing of load of water pollution into the Han River, and the river environment, as well as the problem of water supply, have to be treated with prudence.

Finally, it is pointed out that a comprehensive dam operation rule in the Han River Basin is also a serious theme of study.

\section{CONCLUSION}

Since starting togather with the foundation of the Choseon Dynasty in 1392, the managing system of Korean rivers was framed by establishing of the Geographic Bureau and the Civil Engineering Bureau of the Department of Home Affairs in 1895. During the period from 1910 to 1945, the Colonial Japanese Government had established the plan for river improvement and the construction of levee to control the floods mainly. During the period from 1945 to 1960 , several managing authorities were established and managed the rivers separately. But the lack of the National Budgets for the river managing made their activities insignificant. After 1960 until 1980, there had been a lot of activities for the river management such as the establishment of river managing system, the project of river basinwide surveying, the channel improvement and the water resources development.

Above all, in 1961, the Water Resources Bureau was organized in the Ministry of Construction and a comprehensive master plan including 12 multipurpose dams was established, and other various hydrologic surveys were also carried out in each river basin actively. Since 1980 the urbanization by increasing of population and promotion of industrialization led to a rapid increase of water use. At the same time, water pollutions in the rivers and reservoirs are now being faced. So the counterplans for preservation of water quility, environment and ecosystem should be handled with care and urgency. 
The managing strategy of Korean rivers should be comprehensive, including the flood control, water use, water quality control, and problems of environment and ecosystem, etc., by surveying, planning, the construction and establishment of the counterplans of maintenance and management.

\section{REFERENCES}

1. The Ministry of Construction, Korea, A History of Country Developments : Korea, 1988.11

2. The Ministry of Construction, Korea, Construction of the Country : Korea, 1987.12

3. Choseon Chongdockbu (朝鮮總督府), Survey of Korean River, 1929.

4. Kim, Eui-Won, A Study on the History of Country Development of Korea, University Publ. Co., Seoul, 1982.

5. Sonu, Jungho, Hydrology, Dongmyungsa Publ. Co., Seoul, 1983

6. Won, Tae-Sang, River Engineering, Munoondang Publ. Co., Seoul, 1969. 